\title{
A Strategic Model of the Franchise Form of Business Organization
}

\author{
James W. Brònson
}

James B. Faircloth

As an organizational form, franchising has evolved to the point where it now accounts for 38 percent of U.S. retail sales. The success of the franchise form can be attributed to its inherent competitive advantage. In this article, a franchise model is proposed which integrates aspects of external growth, allowing economies of scale and ultimately creating competitive advantage, with internally generated growth outcomes of lowered costs and differentiation. The integration of external and internal growth components represents the key contribution of this research.

The core competitive advantage is derived from economies of scale. Scale is attained through the acquisition of external financial resources and managerial agents. Once attained, scale economies lead to internal growth through an integrated low-cost, differentiation-based advantage. Low-cost, differentiation advantages are further reinforced through the quality orientation of the franchise system.

B usiness franchising is a particularly American invention. It is part of the history of entrepreneurship in the United States as practiced by the likes of McCormick, Singer, Ford, and Kroc (Dickie, 1992). As amazingly successful as its early creators, today franchising accounts for 38 percent of all U.S. retail trade and generates $\$ 1$ trillion in annual sales (Trutko, Trutko, and Kostecka, 1993).

Undoubtedly due to the franchise form's highly visible success, business researchers have devoted attention to franchising for over thirty years (Oxenfeldt and Kelly, 1968). A number of theoretically grounded arguments for the success of the franchise have been offered (e.g., Brickley and Dark, 1987; Hadfield, 1991; Mathewson and Winter, 1985; Norton, 1988a). These seemingly contradictory arguments address the differing means through which the franchise achieves rapid growth, as well as the objective of that growth (e.g., Carney and Gedajlovic, 1991; Hoffman and Preble, 1991; Martin, 1988; Oxenfeldt and Kelly, 1968; Stephenson and House, 1971). More recently, theoretical development and empirical research on the franchise have started the process of integrating the various arguments favoring franchise success (e.g., Castrogiovanni, Bennett, and Combs, 1995; Combs and Castrogiovanni, 1994; Hing, 1995; Pilling 1991). This arti- cle builds on that integration and proposes a strategic model of the processes and factors that have led to the success of the franchise form of organization.

This article is organized into four sections:

1. A review of the classification and definition of franchising is presented in order to provide a foundation for the remaining sections.

2. Franchising is modeled in terms of business growth through the acquisition of external resources.

3. Internal growth is incorporated into the model through the consideration of low-cost and differentiation-based competitive advantage.

4. A full model of the competitive advantage of franchising is given along with a discussion of the role of quality in the success of the franchise form.

\section{Franchising}

This section reviews the history and definition of franchising.

\section{Evolution of the Franchise and Franchising Classification}

Given the diversity of industries in which the franchise form has met success, it is not surprising that a number of classifications of franchising have been put forth (e.g., Carney and Gedajlovic, 1991; Combs and Castrogiovanni, 1994; Hoffman and Preble, 1991; Pintel and Diamond, 1987; Storholm and Scheuing, 1994). The mostly widely accepted classification distinguishes between those franchises that focus on product and those franchises that focus on format (e.g., Combs and Castrogiovanni, 1994; Kostecka, 1986). The product-format franchise dichotomy might be termed an evolutionary classification of franchising since the product franchise preceded the format franchise by 80 years (Dickie, 1992). Product franchising grew out of the complexities surrounding the distribution of specialized consumer products such as Singer's sewing machine and Ford's automobile. Even today, the technology of the sewing machine and automobile is complex, and these relatively expensive products require specialized support in the areas of financing, training, and maintenance.

The presence of such big-ticket items as automobiles in the product franchise has resulted in a categorical leadership in absolute dollar volume. However, in terms of rela- 
tive dollar volume and number of business establishments, the product franchise is reported to be in decline (Trutko, Trutko, and Kostecka, 1993). Rather, it is the business format franchise that accounts for all of the recent growth in franchising (Trutko, Trutko, and Kostecka, 1993).

The business format franchise arose out of the need for standardization. It owes its start to the increase in travel that accompanied the expansion of the railroads and later the interstate highway system. Travelers had no readily available means of evaluating the quality of such travelers' necessities as filling stations, diners, and lodging establishments. By the 1920 s, oil companies had begun to respond to travelers' needs for a standard of service and quality. They were followed by A \& W Root Beer in 1925, Howard Johnson's in 1935, and others; but the growth of the business format franchise is really a product of the second half of the twentieth century, as typified by Ray Kroc's first McDonalds in 1955.

Unlike the product franchise, the business format franchise tends to view the good or service as less important than the preparation and presentation of the good or service. For example, consumers are often presented with a choice of unfamiliar dining establishments that offer hamburgers of unknown quality. Franchises compete successfully for the hamburger dollar because many consumers prefer to choose a hamburger of known and consistent quality. So consumers are told that McDonalds always makes its Big Macs the same way, so that they taste the same in Seattle, Beijing, and Moscow, and the consumer is pleased because there is no surprise.

\section{Franchising Defined}

General Motors, American Express, and McDonalds all employ franchising in their day-to-day operations. This diversity among franchisers suggests that franchising must be defined with broad-brush strokes.

Franchising is a contractual arrangement in which a franchisee owns and operates a business employing the franchiser's brand name; wherein the franchisee commonly purchases various goods from the franchiser, often for resale. In return, the franchiser receives fees and royalties for the use of his/her brand name and typically provides franchise specific inputs such as operating systems and training. The contractual arrangement also grants the franchiser the right to set and enforce uniform standards of quality upon the franchisee (Milgrom and Roberts, 1992).

This broad definition, like the ensuing model, can be applied to both the product and business format franchise. Nonetheless, observing the growth of the franchise form is not operationally useful to a better understanding of specifically why it has achieved such success. The following section describes an external growth model that creates the foundation for the franchising evolution.

\section{Scale, Spatial Preemption, and External Growth Model}

The franchise evolved as an organizational form with the express purpose of facilitating growth in the distribution and sale of products. Today, the franchise's inherent ability to attract external resources for the purpose of achieving rapid growth remains at the core of the franchise's competitive advantage. Franchisers recruit franchisees in order to obtain external resources. From the franchisee comes the capital and managerial efficiency essential to the growth of the franchise. As depicted in Exhibit 1, when sufficient capital and management are attracted, the franchise will grow to the level where it attains economies of scale in one, or more, of its operations. Simultaneously, a franchise with a highly differentiated product or service will preempt the most advantageous geographical territories and locations before followers can establish a market presence.

The model in Exhibit 1 embodies the four prevalent arguments for the evolution and success of the franchise: (1) the ability to raise scarce capital, (2) managerial efficiency, (3) spatial preemption, and (4) economies of scale (Combs and Castrogiovanni, 1994; Martin, 1988). Common across all four arguments is the objective of growth generated through the control of external resources.

- "Does this venture appear to be following an accepted business model?"

- "Does this venture appear to conform to recognized principles, rules, and standards?"

The literature on the franchise has often held that the four explanations for the success of the franchise are in conflict. For example, Carney and Gedajlovic (1991) and Martin and Justis (1993) are among those who present scarce capital and managerial efficiency as alternative explanations of franchising. In contrast, those that would integrate explanations may be characterized by the arguments of Castrogiovanni, Bennett, and Combs (1995) who conclude "franchisers generally are concerned with both administrative efficiency and resource scarcity, though their concern over one relative to the other may vary somewhat with their particular circumstances." Exhibit 1 represents the broader perspective, as exemplified by Castrogiovanni, Bennett, and Combs (1995) and suggests that the four explanations may be complementary and integral components in the same model.

\section{Financial Resources}

As represented in Exhibit 1, franchisers seek two initial inputs from franchisees: capital and managerial ability. 


\section{Exhibit 1 \\ External Growth of the Franchise}

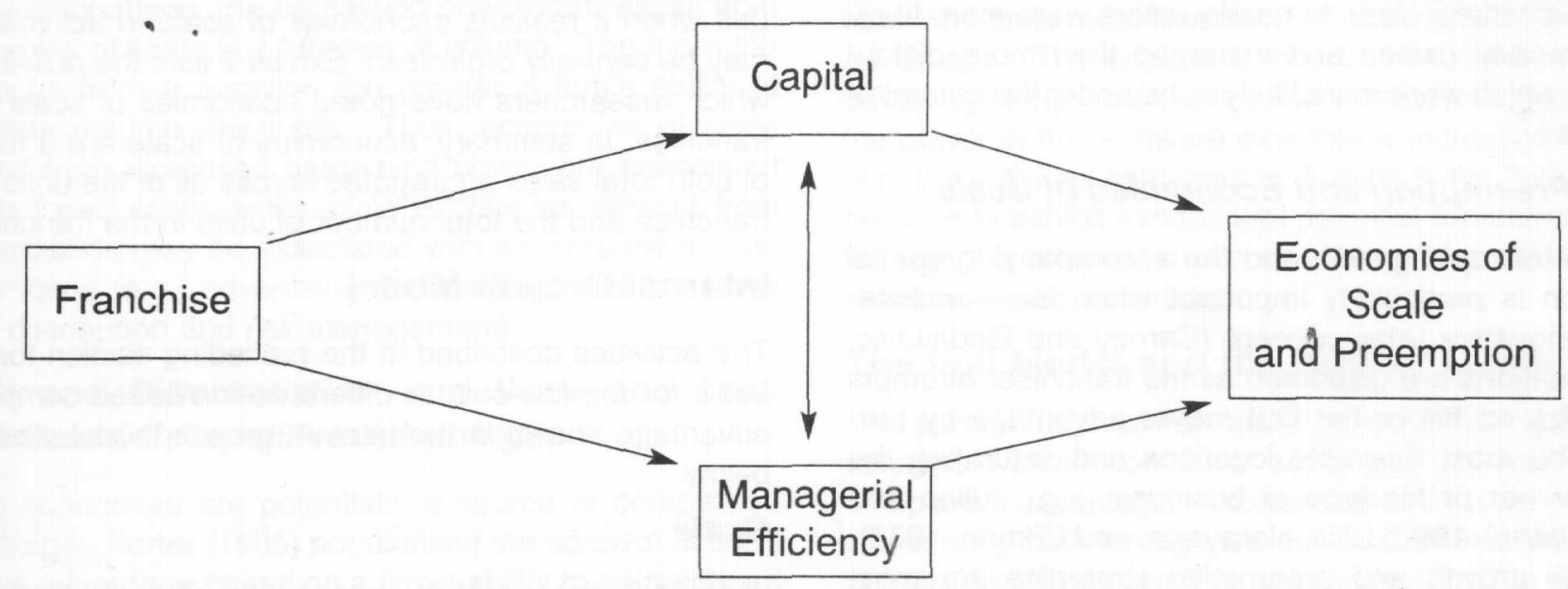

Franchising may be the least expensive way for a franchiser to raise the capital needed for expansion (Oxenfeldt and Kelly, 1968). Facing constraints on the ability to raise growth capital in traditional markets, the franchiser turns to a nontraditional investor, the franchisee. When the franchisee pays for the privilege of expanding the franchise, the franchise grows without tying up capital, incurring debt or lease obligation, or diluting equity. There is no alternative arrangement that will result in a lower cost of capital (Caves and Murphy, 1976). This explanation, despite its face validity, relies on the assumption of capital market imperfections and is not without its critics (e.g. Norton, 1988b; Rubin, 1978). Nonetheless, both Kauffman and Dant (1996) and Carney and Gedajlovic (1991) offer convincing empirical support for the capital acquisition argument.

\section{Managerial Efficiency}

The franchisee and his or her capital are inseparable and necessary components in the growth of the franchise. Reliance on the franchisee for capital also results in the recruitment of an owner-manager whose motivation is aligned with that of the franchiser (Lafontaine, 1992). Simply put, both the franchiser and franchisee have a financial investment in the franchise and thus a mutual interest in the franchise's success. The double arrow connecting capital and managerial efficiency in Exhibit 1 represents the tie between the franchisee's investment and his or her commitment to efficient management.

The franchiser needs more than just capital from the franchisee, because as Penrose (1958) in her classic, The Theory of the Growth of the Firm, points out, the growth of the firm is limited by the availability of managerial talent. A firm or franchise can grow no faster than its ability to indoctrinate its managers into the firm's culture and routines.
The problem is one of agency (e.g., Alchian and Demsetz, 1972; Jensen and Meckling, 1976). For hired management (i.e., the agent), the firm incurs two expenses that are not present when the owner and manager are the same individual. Hired management must be thoroughly indoctrinated into the firm's culture in order to minimize the hired manager's incentive to shirk, or otherwise place her or his interests ahead of those of the firm's owners. This indoctrination, typified by a manager's upward progress through the hierarchy of the firm, often takes years. Not only must agents be indoctrinated, they must be monitored to ensure their actions are in the firm's best interest. Indoctrination, when combined with performance monitoring, results in managerial efficiency.

Indoctrination takes time and monitoring is expensive, thus hired management is a less-than-perfect substitute for ownership. A franchisee, as owner and manager, has his or her wealth invested in the success of the franchise and has no incentive to shirk. This alignment of the franchiser and franchisee's motivation means the time the franchiser must spend on indoctrination is reduced to training in the franchiser's systems and routines. In support of this argument, Norton (1988b) finds that franchising is significantly correlated with agency incentives; while Carney and Gedajlovic (1991) find that both agency considerations and capital acquisition contribute to the growth of the franchise.

The reduction in monitoring costs found in the franchise form of organization may constitute a significant cost advantage because the monitoring problem of agency increases as a function of the spatial dispersion of a firm's locations (Norton, 1988a). That is, as a firm's locations become geographically dispersed, the cost of monitoring managers and enforcing quality standards increases. The franchise, through the alignment of franchiser and fran- 
chisee interests, serves to reduce the travel and bureaucratic costs associated with monitoring the performance of dispersed locations. In support of this argument, both Brickley and Dark (1987) and Lafontaine (1992) found that franchise locations close to headquarters were more likely to be company owned and managed than more distant locations, which were more likely to be under the control of franchisees.

\section{Spatial Preemption and Economies of Scale}

The need for rapid growth and the accompanying spatial preemption is particularly important when the franchiser has an innovative retail concept (Carney and Gedajlovic, 1991). Locations are dispersed as the franchiser attempts to capitalize on his or her first mover advantage by preempting the most desirable locations and saturating the market for her or his type of business (e.g., Julian and Castrogiovanni, 1995; Lillis, Narayana, and Gilman, 1976). Thus, high growth and preemptive strategies are most important for young franchises and this assumption is supported by the findings of Martin and Justis (1993) and Eaton and Lipsey (1979).

The desire to capitalize on a franchise's first-mover advantage leads to rapid growth, the end result of which may be the attainment of economies of scale (e.g., Hoffman and Preble, 1991; Martin, 1988). Economies of scale are reached when the average unit cost of a given activity or product can be shown to decrease as the quantity produced increases (Sheperd, 1990). Franchises attain economies of scale on two levels. Scale may be realized as a result of the totality of sales across all units in the franchise. Scale on this level is characterized by volume discounts in purchasing. Economies of scale may also be a function of the number of units in the franchise. For example, national advertising is only of benefit if the franchise has a sufficient number of units with a national dispersion. In the later case, Caves and Murphy (1976) stress the effi- cacy of the franchise as the ability to centrally coordinate the activities associated with scale while decentralizing the benefits associated with scale. Thus, the franchise is an organizational form that provides a cost advantage to each unit when it realizes economies of scale in activities that may be centrally organized. Exhibit 2 lists the activities for which researchers have noted economies of scale in the franchise. In summary, economies of scale are a function of both total sales aggregated across all of the units in the franchise and the total number of units in the franchise.

\section{Internal Growth Model}

The activities described in the preceding section form the basis for the low-cost or differentiation-based competitive advantage shown in the internal growth model presented below.

\section{Scale}

While it is the quest for economies of scale that drives external growth, it is the attainment of economies of scale that forms the basis for internal growth. These economies of scale arise when a firm is able to realize savings in any one, or a combination, of two actions-the amortization of fixed costs and an increase in bargaining power. In turn, the franchise's inherent ability to amortize costs, as well as its advantageous bargaining position, may result in competitive advantage (Martin and Justis, 1993).

The ability to amortize fixed costs is a function of the degree of specialization in the franchise organization. Like economies of scale, specialization is a function of size (e.g., Blau, 1970; Williamson, 1979) and thus the level of specialization and scale appear to be highly correlated in the franchise. In order to achieve the benefits of scale, each activity listed in Exhibit 2 requires a centralized departmental function. For example, consider that specialized assets are required to create and maintain software capable of tracking a customer's product prefer-

\section{Exhibit 2}

Franchise Activities Subject to Economies of Scale
National bra
Distribution
Information systems
Risk management
Training
Quantity discounts

\author{
Caves and Murphy, 1976 \\ Mathewson and Winter, 1985 \\ Litz and Stewart, 1998 \\ McGuire, 1971 \\ Stephenson and House, 1971 \\ Oxenfeldt and Kelly, 1968 \\ Martin, 1988 \\ Mendelsohn, 1985 \\ Pilling, 1991
}


ences. The ability to amortize the cost of this specialized software is a function of the scale of the franchise's operations; that is, the unit cost decreases as a function of the number of franchise units and customers served.

By comparispn, the bargaining power that results from economies of scale is a function of volume. The more the firm buys from a supplier, the greater a firm's ability to negotiate volume discounts. Thus, economies of scale derived from increased bargaining power are associated with reduced costs, while scale economies derived from specialization may be associated with an increase in customer focus (e.g., advertising and training) and low costs (e.g., distribution and risk management).

\section{Scale and Differentiation, and Scale and Low- Cost Based Competitive Advantages}

Scale economies are potentially a source of competitive advantage. Porter (1985) popularized the concept of competitive advantage based on a firm's ability to gain either a cost-based or a differentiation-based advantage over its competition. Hill (1988) made the argument for competitive advantage based on both low cost and differentiation. In his arguments for a simultaneous low-cost and differentiation-based advantage, Hill (1988) states that economies of scale may be a source of both low-cost and differentiation-based advantages. To illustrate Hill's argument, consider that a franchise may choose to develop specialized software that tracks customer preferences. This attention to the customer's needs should increase customer satisfaction and loyalty, thus differentiating the firm from its competitors and increasing its competitive advantage as noted in Exhibit 3. This increase in the level of differentiation will result in a higher sales volume. A rise in sales vol- ume translates into a need to purchase inputs in larger quantities which will increase the firm's bargaining power relative to its suppliers, thus decreasing the firm's costs for inputs as represented in Exhibit 3. The decrease in the cost of inputs contributes to a cost-based competitive advantage. The argument may be reversed: a low-cost advantage may increase the firm's ability to differentiate. If the power of this software example is increased by several of the activities contained in Exhibit 3, the franchise can be seen to exhibit exceptional potential for internal growth through the attainment of a simultaneous cost- and differentiation-based advantage.

\section{The Full Model and the Role of Quality}

The purpose of external resource acquisition is the timely attainment of economies of scale and the accompanying competitive advantage. A consequence of scale economies is internal growth through low-cost and differentiation-based competitive advantage. Franchises leverage the economies of scale noted in the external model into competitive advantage in the marketplace, either through low-cost or differentiation. Hence, external and internal growth are linked through economies of scale as represented in Exhibit 4. In addition to combining Exhibits 1 and 3, Exhibit 4 incorporates a feedback loop representing the contractual responsibilities of the franchise agreement.

The contract between the franchiser and franchisee grants the franchiser the right to set and enforce uniform quality standards on the franchisee (Milgrom and Roberts, 1992). The feedback loop in Exhibit 4 represents, in part, this quality monitoring and the effect of quality standards on franchise performance. Quality products and services increase sales contributing to the early attainment of scale

\section{Exhibit 3}

Internal Growth of the Franchise

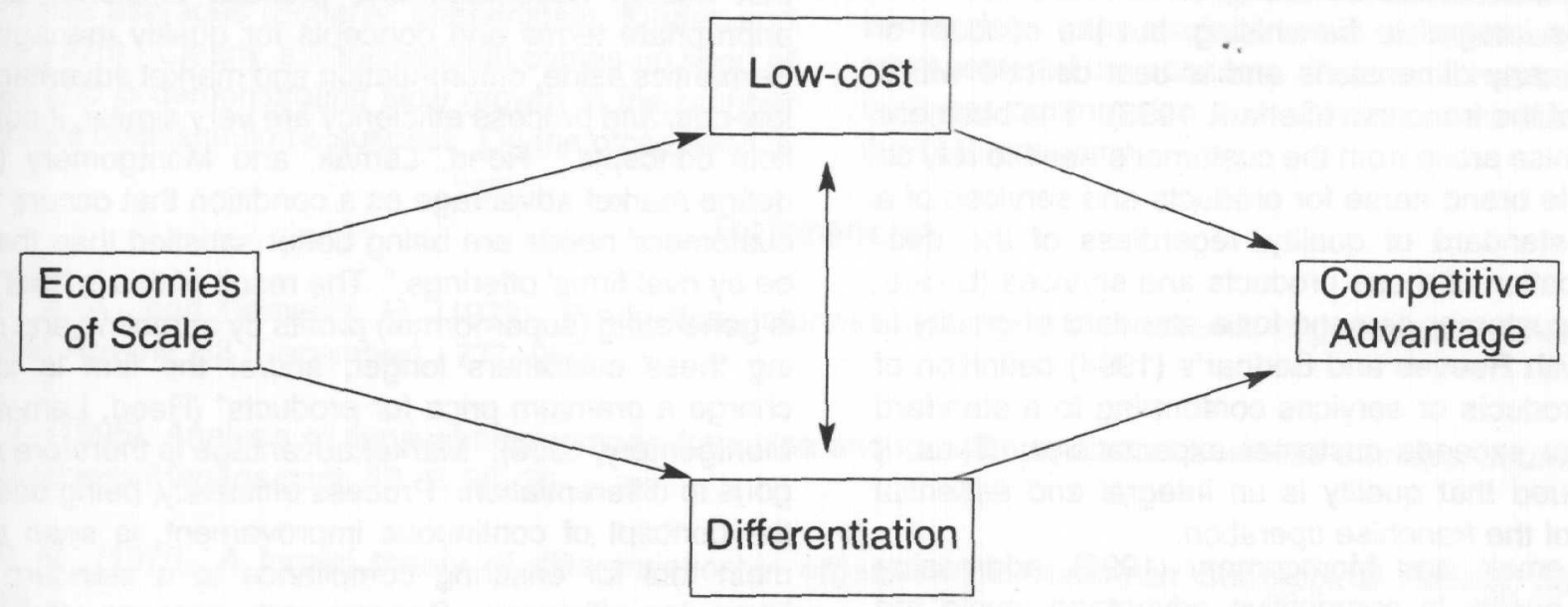


Exhibit 4

Competitive Advantage of the Franchise-The Full Model

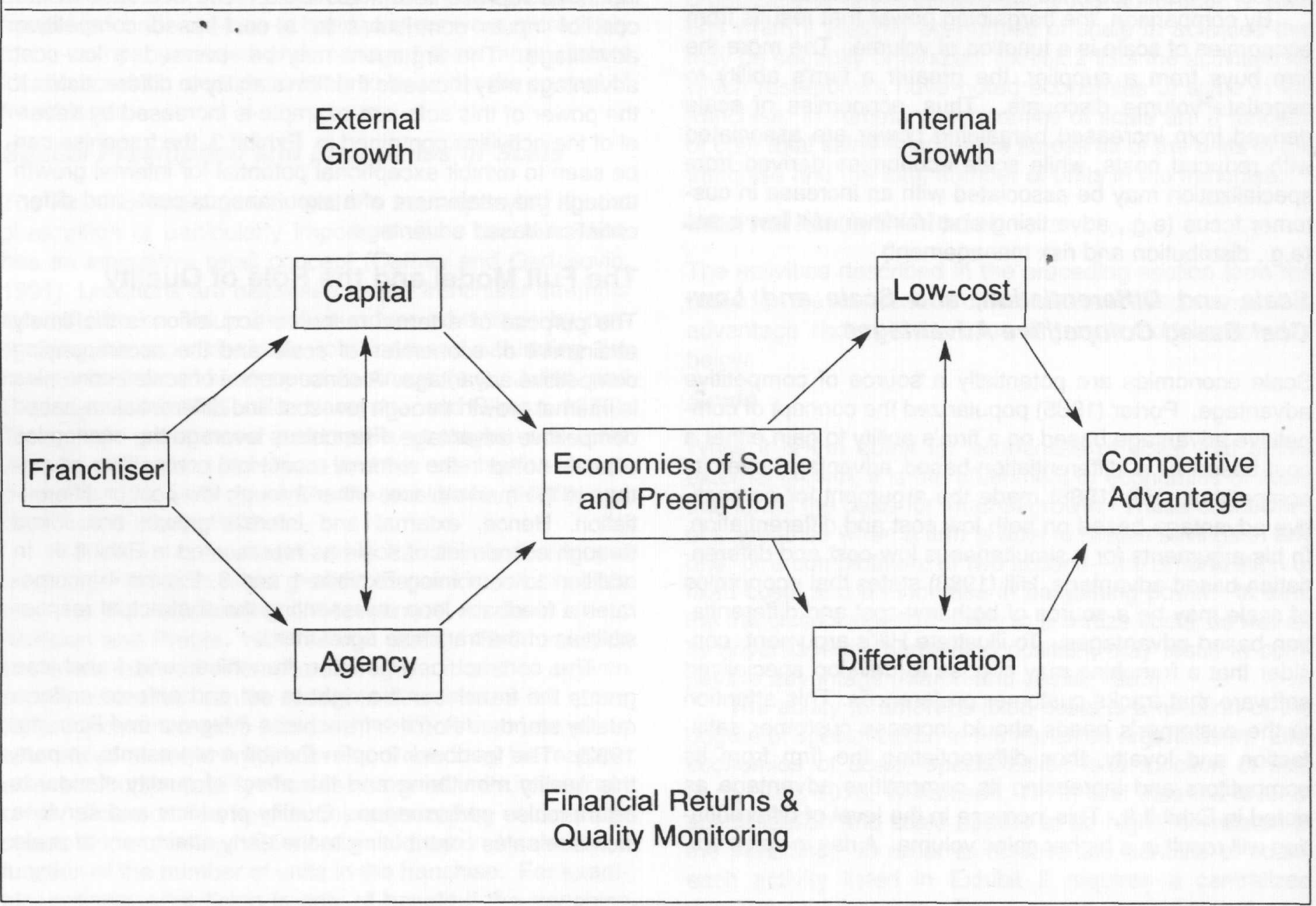

economies and, not unlike economies of scale, quality may also be associated with the attainment of low-cost and differentiation-based advantages.

Quality is integral to franchising, but the concept of quality has many dimensions and is best defined within the context of the franchise (Gehani, 1993). The business format franchise arose from the customer's need to rely on an identifiable brand name for products and services of a predictable standard of quality, regardless of the geographical location of those products and services (Dickie, 1992). This customer demand for a standard of quality is consistent with Reeves and Bednar's (1994) definition of quality as products or services conforming to a standard that meets or exceeds customer expectations. Thus, it may be argued that quality is an integral and essential component of the franchise operation.

Reed, Lemak, and Montgomery (1996), addressing the role of quality in competitive advantage, avoid the terms differentiation and low-cost because these terms are derivatives of the economic discipline. Instead, they argue that market advantage and process efficiency are the appropriate terms and concepts for quality management. Semantics aside, differentiation and market advantage and low-cost and process efficiency are very similar, if not identical concepts. Reed, Lemak, and Montgomery (1996) define market advantage as a condition that occurs "when customers' needs are being better satisfied than they can be by rival firms' offerings." The result of this is "that a firm is generating (supernormal) profits by attracting and retaining these customers longer, and/or the firm is able to charge a premium price for products" (Reed, Lemak, and Montgomery, 1996). Market advantage is therefore analogous to differentiation. Process efficiency, being based on the concept of continuous improvement, is seen as the main tool for ensuring compliance to a standard while improving efficiency. Consequently, process efficiency is 
only a part of the greater low-cost construct which includes other paths to reduced costs, including economies of scale and the resultant bargaining power over suppliers (Reed, Lemak, and Montgomery, 1996). Thus, pursuit of a quality standard in itself may result in a differentiation and lowcost based competitive advantage.

It is the centralized monitoring of the franchisee that ensures quality and performance will be realized by the greater franchise organization. However, it is not enough to simply enforce a fixed standard of quality. Only if the franchiser uses feedback from the franchisee to constantly improve the quality of goods and services, will a competitive advantage be sustained.

\section{Application}

The development of the model of the strategic advantage of the franchise suggests lessons applicable to the marketplace. Franchises are not necessarily successful; indeed Bates (1995) documents a greater failure rate for new iranchisees than new independent businesses over a four-year period in the 1980s. A high failure rate for new franchisers has also been noted (Bates, 1995). Franchisee failure is due to a number of factors, but the failure of the franchise to achieve economies of scale, whether due to saturated markets or other reasons, may be the most common. This suggests that both the potential franchiser and franchisee should carefully evaluate the likelihood of the franchise attaining economies of scale.

From the franchisee's perspective, the initial question should be whether, or not, the franchise has attained sufficient size to achieve economies of scale in procurement and one, or more, specialized activities. This is not an easy task, since economies of scale are both process and industry specific. Nonetheless, there are key indicators; for example, the average number of units within a franchise in the industry, or in a comparable industry. The use of the average number of units, while superficially simplistic, is consistent with two common economic measures of scale-the survivor test (Stigler, 1958) and the top 50percent size averages (Scherer, Beckenstein, Kaufer, and Murphy, 1975). Clearly, a franchise that comes up short of average and is demonstrating slow growth in the number of franchise units should be suspect. On the other hand, a franchise with a high growth rate, above average number of units, or both, is more likely to achieve, or have achieved, economies of scale.

Achieving economies of scale in one area may not be sufficient to ensure a competitive advantage. Franchisees should examine the number of areas in which the franchise has, or is likely to, achieve a competitive advantage. Clearly, a hotel franchise with brand name recognition, a reservation system, a training program and scale economies in procurement is of greater potential value than a hotel chain with only brand name recognition. Indeed, it may be that positive brand name recognition and an efficient reservation system are inseparable for a franchised hotel system.

Finally, the strictest attention should be paid to the extent the franchiser enforces the quality standards of the franchise. The business format franchise evolved as a business form for the express purpose of offering the public a good or service of predictable quality regardless of physical location. Any fluctuation in quality from locationto-location across the franchise is a threat to the franchisee.

\section{Conclusions}

That franchising follows accepted theories of strategic competitive advantage is anything but a coincidence. The franchise emerged in the U.S. before the Civil War due to the need to distribute and service complex consumer products invented by entrepreneurs like Singer and McCormick. Today's franchise is the result of more than 150 years of trial and error (Dickie, 1992). During its evolution, the franchise developed a dual approach to growth, employing both external and internal resources to achieve both a differentiation and cost-based competitive advantage. Customer demands also forced the franchise to focus on quality long before quality management techniques were popularized across the business landscape. This emphasis on growth and quality has allowed the businesspeople who employ the franchise form of business organization to consolidate many markets within the relatively fragmented retail sector of the economy. The result has been a form of business organization that currently dominates retailing in the U.S economy.

\section{References}

Alchian, A. A., and Demsetz, H. (1972). Production, information costs and economic organization. American Economic Review, 62 (December), 777-950.

Bates, T. (1995). Analysis of survival rates among franchise and independent small business startups. Journal of Small Business Management, 33, 2, 26-36.

Blau, P. M. (1970). A formal theory of differentiation in organizations. American Sociological Review, 35, 2, 201-218. 
Brickley, J. A. ; and Dark, F. H. (1987). The choice of organizational form: The case of franchising. Journal of Financial Economics, 18, 401-420.

Carney, M., and Gedajlovic, E. (1991). Vertical integration in franchise systems: Agency theory and resource explanations. Strategio Management Journal, 12, 607-629.

Castrogiovanni, G. J., Bennett, N., and Combs, J. G. (1995). Franchisor types: Reexamination and clarification. Journal of Small Business Management, 33, 1, 53-54.

Caves, R. E., and Murphy II, W. F. (1976). Franchising: Firms, markets and intangible assets. Southern Economics Journal, 42, 572-586.

Combs, J. G., and Castrogiovanni, G. J. (1994). Franchisor strategy: A proposed model and empirical test of franchise versus company ownership. Journal of Small Business Management, 32, 2, 37-48.

Dickie, T.S. (1992). Franchising in America. Chapel Hill, NC: University of North Carolina Press.

Eaton, B. C., and Lipsey, R. C. (1979). The theory of market preemption: The persistence of excess capacity and monopoly in growing spatial markets. Economics, 46, 182, 149-158.

Gehani, R. R. (1993). Quality value-chain: A meta-synthesis of frontiers of quality movement. Academy of Management Executive, 7, 2, $29-42$.

Hadfield, G. K. (1991). Credible spatial preemption through franchising. The Rand Journal of Economics, 22, 4 , 531-543.

Hill, C. W. L. (1988). Differentiation versus low-cost or differentiation and low-cost: A contingency framework. Academy of Management Review, 13, 3, 401-412.

Hing, N. (1995). Franchisee satisfaction: Contributors and consequences. Journal of Small Business Management, $33,2,12-25$.

Hoffman, R. C. , and Preble, J. F. (1991). Franchising: Selecting a strategy for rapid growth. Long Range Planning, $24,4,74-85$.

Jensen, M. C., and Meckling, W. H. (1976). Theory of the firm: Managerial, agency costs and ownership structure. Journal of Financial Economics, 3, 305-360.

Julian, S. D., and Castrogiovanni, G.J. (1995). Franchisor geographic expansion. Journal of Small Business Management, 33, 2, 1-11.

Kauffman, P. J. , and Dant, R. P. (1996). Multi-unit franchising: Growth and management issues. Journal of Business Venturing, 11, 343-358.

Kostecka, A. (1986). Franchise Opportunities Handbook. Springfield, VA: U.S. Chamber of Commerce.

Lafontaine, F. (1992). Agency theory and franchising: Some empirical results. The Rand Journal of Economics, 23, 2, 263-283.

Lillis, C. M., Narayana, C. L., and Gilman, J. L. (1976). Competitive advantage variation over the life-cycle of a franchise. Journal of Marketing, 40, 77-80.

Martin, R. E. (1988). Franchising and risk management. The American Economic Review, 78, 5, 954-968. 
Martin, R. E., and Justis, R. T. (1993). Franchising, liquidity constraints, and entry. Applied Economics, 25, 9, $1269-1277$.

Mathewson, G. F., and Winter, R. A. (1985). The economics of franchise contracts. The Journal of Law Economics, $28,3,503-526$.

Milgrom, P. R., and Roberts, J. (1992). Economics, Organization and Management. Englewood Cliffs, NJ: PrenticeHall.

Norton, S. W. (1988a). Franchising, brand name capital, and the entrepreneurial capacity problem. Strategic Management Journal, 9, 105-114.

Norton, S. W. (1988b). An empirical look at franchising as an organizational form. Journal of Business, 61, 2, 197-218.

Oxenfeldt, A., and Kelly, A. O. (1968). Franchising in perspective. Journal of Retailing, 3, 69-83.

Penrose, E. T. (1958). The Theory of the Growth of the Firm. New York: Wiley.

Philling, B. A. (1991). Assessing competitive advantage in small businesses: An application to franchising. Journal of Small Business Management, 29, 4, 55-63.

Pintel, G., and Diamond, J. (1987). Retailing. Upper Saddle River, NJ: Prentice-Hall.

Porter, M. E. (1985). Competitive Advantage. New York: Free Press.

Reed, R., Lemak, D. J., and Montgomery, J. C. (1996). Beyond process: TQM content and firm performance. Academy of Management Review, 21, 173-202.

Reeves, C.A., and Bednar, D. A. (1994). Defining quality: Alternatives and implications. The Academy of Management Review, 19, 419-445.

Rubin, P. H. (1978). The theory of the firm and the structure of the franchise contract. Journal of Law and Economics, 21, 223-233.

Scherer, F. M., Beckenstein, A., Kaufer, E., and Murphy, R. D. (1975). The Economics of Multi-Plan Operation: An International Comparisons Study. Cambridge, MA: Harvard University Press.

Sheperd, W. G. (1990). The Economics of Industrial Organization. Englewood Cliffs, NJ: Prentice-Hall.

Stephenson, P. R. , and House, R. G. (1971). A perspective on franchising. Business Horizons, 14, 4, 35-42.

Stigler, G. J. (1958). The economies of scale. Journal of Law and Economics, 1, 54-71.

Storholm, G., and Scheuing, E. E. (1994). Ethical implications of business format franchising. Journal of Business Ethics, 13, 181-188.

Trutko, J. and Kostecka, A. (1993). Franchises Growing Role in the U.S. Economy, 1975-2000. Springfield, VA: U.S. Department of Commerce.

Williamson, O. E. (1979). Transaction-cost economics: The governance of contractual relations. Journal of Law and Economics, 22, 233-261. 


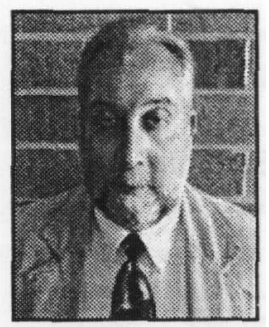

James W. Bronson, an assistant professor of management at the University of WisconsinWhitewater, left the construction industry to further his understanding of business in the academic arena. He received his Ph.D. from Washington State University in 1995 and currently teaches courses in business policy and entrepreneurship. His research interests focus on competitive adkantage, business networks, and the effects of natural disasters on business communities. His work includes publications in Journal of Business Research, Journal of Small Business Management, Psychological Reports, case studies, and numerous conference papers.

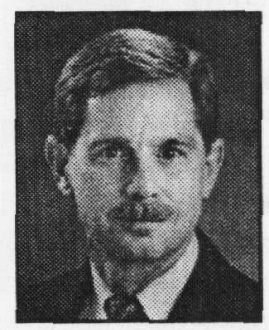

James B. Faircloth is an assistant professor of marketing at the University of Wyoming. He received his D.B.A. in marketing from Mississippi State University in 1996. He is currently teaching courses in marketing management, entrepreneurship, and marketing principles. His research interests are primarily in brand equity and brand image and small business marketing issues. He has published in such outlets as the Journal of Marketing Theory and Practice, Sport Marketing Quarterly, Journal of Food Products Marketing, and Journal of Hospitality and Leisure Marketing. 